\title{
Dansk Vestindiens helte og heltinder
}

\author{
AF RIKKE LIE HALBERG \& BERTHA REX COLEY \\ SLAGMARK \#75 \\ SIDER: $33-44$
}

\begin{abstract}
"Now you are free. You are hereby emancipated!" Historien om Peter von Scholten som en helt og de slavegjortes befrier er et veletableret narrativ i Danmark. I dag betragter de fleste mennesker slaveriet som en uhyrlighed, og fortællingen om, hvordan den danske generalguvernør von Scholten gjorde en ende på slaveriet på trods af kongens ordrer i 1848, er en fortælling, den moderne dansker kan identificere sig med. Men på trods af kanoniseringen af von Scholten i det man kan kalde det danske perspektiv på historien om Dansk Vestindien, er han ikke videre vigtig i den version, man kan finde på de amerikanske Jomfruøer. Historien om afskaffelsen af slaveriet i Dansk Vestindien begynder og ender ikke med von Scholten. Tværtimod handler den historie først som sidst om de slavegjorde afrikansk-caribiere, som siden koloniens etablering igen og igen forsøgte at gøre oprør mod slavegørelsen. Fortællinger om modstanden er blevet bevaret både i og udenfor arkiverne. I arkiverne dokumenteres modstanden som en gene for det koloniale system og oprørerne beskrives indenfor denne forståelsesramme. Men samme fortællinger forstås helt anderledes i afrikansk-caribiske sange og i den mundtlige tradition, der er blevet overleveret fra forældre til børn og fra lærere til elever (Bastian, 2006). I disse fortællinger beskrives de samme mennesker, som koloniadministrationen betragtede som en plage - eller endda som skurke - som helte. Denne artikel diskuterer, hvorfor Dansk Vestindiens afrikansk-caribiske skurke/helte endnu ikke er blevet en fuldt integreret del af det danske narrativ om modstand, abolitionisme og borgerrettigheder. Kan "vi" acceptere helte, som ikke er hvide, men efterkommere af mennesker, der blev holdt som slaver af danskere og som gjorde oprør mod det danske styre?
\end{abstract}




\section{ERINDRING}

Det er ofte blevet sagt, at dansk kolonihistorie er blevet glemt. Ser man nærmere efter, kan man se, at det ikke forholder sig sådan, selvom det er helt tydeligt, at kolonitiden er blevet marginaliseret i en dansk kontekst, og at den primært er blevet husket som en ærefuld tid. Der er en række grunde til, at denne udlægning kun sporadisk er blevet udfordret. En af dem er, at kun fă tidligere koloniserede mennesker har boet i Danmark og derfor ikke har haft mulighed for at igangsætte eller deltage i en debat om, hvordan den fælles historie blev forstået af folk i periferien af kolonimagten (Nonbo Andersen, 2013). Storpolitik, handel og søfartshistorie var hovedinteressen i den historiske forskning i Dansk Vestindien gennem det meste af det 20. århundrede (Sebro, 2010). Undervisningsmateriale og museumsudstillinger fulgte også denne tendens (Halberg, 2016a). Men i de senere år er et styrket fokus på kritisk forskning blevet tydeligt. ${ }^{1}$ Der er også eksempler på nye undervisningsmaterialer til grundskolen og ungdomsuddannelserne. ${ }^{2}$ Endelig er der i løbet af 2017 en række museer og andre kulturinstitutioner som planlægger nye udstillinger med et kritisk og/eller aktivistisk perspektiv. ${ }^{3}$

Historiske monumenter og erindringssteder er vigtige for den måde, hvorpå et samfund husker begivenheder eller folk (Sørensen, 2010). Det faktum at der endnu ikke er et monument eller erindringssted for slaveriet i Danmark, har været debatteret i danske medier de senere år (Rothstein, 2015; Bjørn, 2016). Som et svar på denne debat, tilbød St. John Historical Society Danmark en gave i form af tre prototyper af skulpturer i efteråret 2016. Alle tre skulpturer repræsenterer oprør, modstand og forandring idet de portrætterer henholdsvis en frihedskæmper som blæser i en konkylie og hæver en machete, oprørslederen General Buddhoe og redaktøren og fagforeningslederen David Hamilton Jackson. Disse skulpturer blev skabt af den amerikansk-ghanesiske kunstner Bright Bimpong i 1998 til minde om afskaffelsen af slaveriet 150 år tidligere. Skulpturerne blev opstillet på St. Croix, St. Thomas og St. John (men altså ikke i Danmark). I Danmark arbejder kunstneren Jeannette Ehlers i øjeblikket på en skulptur af Queen Mary, en kvindelig oprørsleder fra Fireburn-opstanden på St. Croix i 1878. Disse skulpturer indikerer alle vigtigheden af en række heroiske figurer på de amerikanske Jomfruøer. De bliver fejret som helte på Jomfruøerne i dag, på offentlige steder, i skoler og i populærkulturen (Halberg \& Coley, 2016). 
Heltefigurerne har været integreret i historieundervisningen fra grundskole- til universitetsniveau på Jomfruøerne i mange år (Hill, 1983; Hall, 1992; Willocks, 1995). Men de er også et godt udgangspunkt for undervisning i kolonihistorien i det danske skolesystem. I resten af artiklen vil vi diskutere forskellige syn på, fortolkninger og brug af heltene General Buddhoe, Queen Mary og Jackson. Det fælles for disse historiske personer er, at de er af afrikansk herkomst, levede på Jomfruøerne under dansk styre og blev involveret i modstand, revolter og forsøg på at reformere det danske koloniale system på forskellige niveauer.

Uanset om de blev holdt som slaver eller, som senere, var undersåtter i den danske stat, blev afrikansk-caribiere altid henvist til som et "dem" og altså ikke som et "os", på trods af at man indimellem i god mening, men også lettere sarkastisk, kaldte dem "vore vestindiske landsmænd" (Halberg, 2016a). Historien om den danske koloni i Vestindien består dermed af kontrasterende narrativer: kolonimagtens og de koloniseredes.

\section{GIVE ELLER TILKÆMPE SIG FRIHED: PETER VON SCHOLTEN OG GENERAL BUDDHOE}

De to narrativer sameksisterer og konkurrerer af og til i fortællingen om emancipationen i 1848. I Danmark er von Scholten blevet tilskrevet rollen som helt, ikke så meget i kraft af forskning som af populærkultur, fiktion og semi-fiktion. Preben Ramsbølls ungdomsroman Massa Peter dannede basis for DRs tv-serie i 1981. Thorkild Hansens Slavernes Øer fra 1971 og filmen Von Scholten fra 1987 er andre eksempler på populærkultur, der har været vigtig for dannelsen af brede opfattelser af kolonihistorien. Det, disse værker har tilfælles, er, at de præsenterer von Scholten som den, der giver de slavegjorte deres frihed, men at de samtidig også inkluderer Buddhoe som en vigtig historisk figur, om end mest som en sidefigur, der styrker von Scholtens heroiske karakter. På de amerikanske Jomfruøer er Buddhoe meget vigtigere og fejres som 1848's største helt, lige såvel som man fortæller historien om friheden som noget man tilkæmpede sig - og ikke en man blev givet.

Avisen Foedrelandet, redigeret af C.N. David, var ekstremt kritisk indstillet overfor det danske kolonistyre i almindelighed og von Scholten i særdeleshed. ${ }^{4}$ David og Fædrelandet understøtter ideen om at frihed i $1848 \mathrm{ikke}$ blev givet, men blev taget af oprørerne selv: 
"Det er i sig selv en uoprettelig Skade, at det er Negrene som har tilrevet sig deres Frihed, at det ikke er os, som frivilligt har skænket dem den. For Erindringen om denne Handling vil faa Negrene til at indbilde sig, at de er overlegene, de vil tro, at de har sejret over de Hvide, og hvor vanskeligt vil det ikke være at forbinde en saadan Illussion med lydig Underkastelse under de Hvides Love" (David, 1848).

Navnet Buddhoe kan genfindes i retsprotokoller, hvoraf det helt tydeligt fremgår, at han spillede en vital rolle i begivenhederne i juli 1848. Han nævnes i mange vidneudsagn som den vigtigste leder, og han nævnes også i mange andre tekster, herunder tekster skrevet af Frederik von Scholten (Peter von Scholtens bror), som efter oprøret skrev fra St. Croix, at Buddhoe var oprørets leder, og at det var ham, der sikrede, at det ikke førte til blodsudgydelser. Ikke desto mindre har historikere senere sat spørgsmålstegn ved hans eksistens, primært fordi hans "rigtige" navn (som måske var John, Moses, Gottlieb eller Bordeaux) ikke kan findes i nogen plantagelister (Bastian, 2003). Dette spørgsmålstegn blev angrebet i en kronik i The Virgin Islands Daily News i 1998:

\footnotetext{
Under diskussioner af 1848-opstanden gav det mig kvalme at lytte til vise "eksperters" fortolkning af opstanden og oprørerne. Jeg blev forarget over at høre visse ikke-afrikanere informere mig om, at Buddhoe ikke havde eksisteret, fordi de danske registre ikke havde anført Moses Gottlieb som den centrale anfører [...] en forfærdelig følelse overvældede mig, når jeg hørte ikke-afrikanere informere mig om, at ifølge koloniale og særligt danske fortegnelser eksisterede min helt slet ikke (Sekou, 1998).
}

På Jomfruøerne holdes mindet om Buddhoe i live både i historieundervisningen og i mundtlige traditioner, hvor særligt den populære folkesangsgenre cariso (en folkesang der historisk set er blevet brugt til at sprede Nyheder eller mindes begivenheder). Mindet om Buddhoe findes særligt i sangen Clear de Road: "Leh we meet de Gen'ral, Gen'ral name is Buddhoe, He gon' gi we freedom”.

\section{KRIMINELLE ELLER HELTINDER: THE FIREBURN QUEENS}

Andre vigtige historiske figurer, der bliver mindet på de amerikanske Jomfruøer, er de såkaldte Fireburn dronninger. Til trods for emancipationen i 1848, gjorde 
den danske stat ikke meget for at forbedre forholdene for den afrikansk-caribiske befolkning. Dette førte i 1878 til et oprør på St. Croix, der kendes som "Fireburn" på Jomfruøerne. Fireburn var den største arbejderrevolte i Danmarkshistorien (Marsh, 1981; Hoxcer Jensen, 1998). Umiddelbart efter Fireburn blev 400 mennesker arresteret, inklusive fire kvinder som blev betragtet som oprørets ledere: Mary, Agnes, Mathilda og Susanna. Disse kvinder afsonede deres fængselsdom i kvindefængslet på Christianshavn. Mary var indsat her fra 1882-1887. Retsprotokoller efter retsopgøret og fængselsprotokoller dokumenterer kvindernes eksistens, men siger kun meget lidt om kvindernes motiver. Protokollerne blev skrevet af politimænd i den danske koloniadministration eller af danske fængselsvagter, og fokuserer mest på, hvordan kvinderne ser ud og opfører sig: Thomas beskrives med adjektiver som sort, lille, buttet, fuld og voldelig, og det nævnes, at hun tidligere har været indsat for at slå sit barn.

I fængselsprotokollen fra kvindefængslet på Christianshavn står der om Thomas, at hun under revolten "var en af de voldsomste til at ægge Mændene til Ødelæggelse" (Christianshavns Straffeanstalt, Protokol over kvindefanger m.fl. (1854-1925)). Enkelte tegninger af Queen Mary fra 1880erne viser en stovt kvinde med en fakkel, en machete og vidt åbne øjne, der lyser af vrede - langt fra datidens kvindeidealer. Fireburn var en af de få nyheder fra Dansk Vestindien, der i samtiden nåede danske medier. Arbejderavisen Social-Demokraten dækkede revolten, først i en ret fordømmende tone, men senere med større sympati for opstanden. Revolten blev også nævnt i Illustreret Tidende, et månedsblad af mere populær karakter. Her beskrives revolten under rubrikken "Negrenes Udskeielser paa St. Croix" som en begivenhed, hvor sorte ødelagde øen St. Croix uden grund:

En ulykkelig Stjærne hviler over St. Croix. Øen har i en Række af Aar staaet under et Oekonomisk Tryk paa grund af Høstens utilfredsstillende Udfald; iaar tegnede alt fortræffeligt, og saa gribes

Negrene af en Ustyrlig Ødelæggelseslyst, der ikke blot kuldkaster de gode Forhaabninger, men styrter Befolkningen i Nød og Elendighed (Illustreret Tidende, 1878).

Revolten optræder også i datidens tabloidmedie, nemlig skillingsvisen - en balladeform, der blev opført af gademusikanter. Balladen beskriver at årsagen til revolten var at den sorte mand Sjang, ikke gad arbejde men ville have fløde på sin havregrød. Da han ikke kunne få det, stak han plantageejeren ned og satte revolten i gang. De 
fleste danske kilder forholder sig skeptisk overfor revolten og er ofte udtalt racistiske.

Men de danske kilder viser også, at Thomas blev kaldt "dronning" af andre afrikansk-caribiske arbejdere på den plantage hvor hun arbejdede. "Queen", dronning, var en ærestitel som man gav til kvinder, der havde høj status, en særlig viden og blev betragtet som ledere (Oliver, 2009). Fireburn bliver beskrevet som en revolte uden årsag, og Thomas som en art "forkert" kvinde i de danske kilder. Alligevel indikerer hendes titel, at hun havde andre kvaliteter end dem, der blev nedskrevet af den danske koloniadministration. På Jomfruøerne er det denne titel, der har holdt liv i fortællingen om Thomas: Dronning Mary. Ligesom i sagen om Buddhoe, har den mundtlige overlevering spillet en vigtig rolle for mindet om Fireburn som en modstandshandling og dets ledere som frihedshelte. En anden cariso-sang, Queen Mary, er også blevet overleveret igennem generationer, og Fireburn dronningerne æres og mindes generelt på Jomfruøerne som kvinder, der gjorde modstand mod et undertrykkende dansk styre:

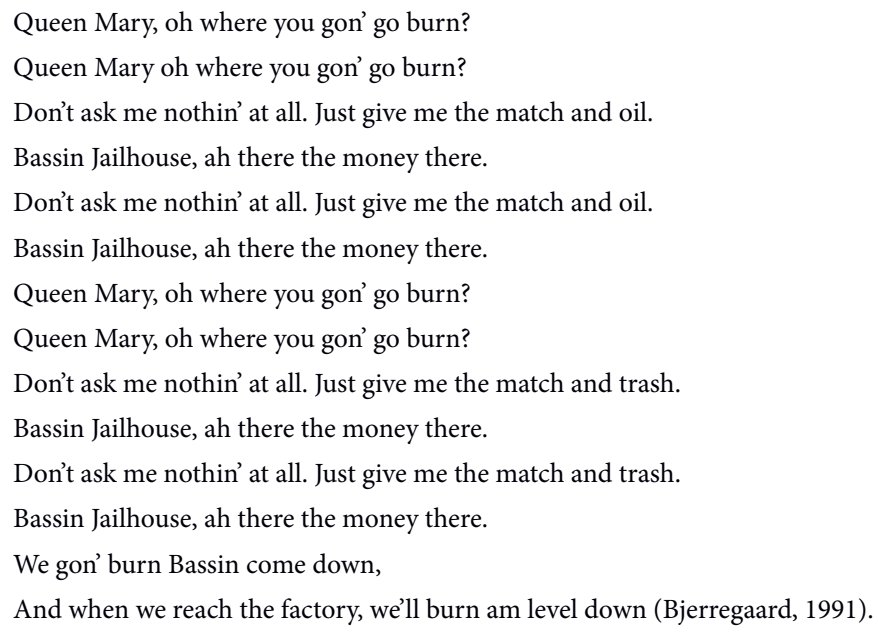

Fortællingen om Fireburn som en modstandshandling er levende på Jomfruøerne. Den formidles på skoler såvel som i det offentlige rum: Hovedvejen på St. Croix, der under det danske styre blev kaldt "Kongevejen", og som i første omgang fik det mere 
neutrale "Centerline" efter 1917, er senere blevet omdøbt til "Queen Mary Highway". Dronningerne mindes også med en statue af tre af de fire dronninger (den fjerde Fireburn dronning, Susanna, blev først identificeret for få år siden). Disse forskellige erindringssteder understreger vigtigheden af disse kvinders eftermæle på Jomfruøerne. Vigtigheden af Fireburn som en modstandshandling i Dansk Vestindien er begyndt at få stigende opmærksomhed i Danmark. Fireburn diskuteres i nyt undervisningsmateriale (Halberg \& Coley, 2016; Halberg \& Christensen, 2017), og der er blevet skrevet artikler om det (Damkjær \& Scherfig, 2016; Halberg, 2016). I udstillings- og kunstsammenhænge har Arbejdermuseet en afdeling om Fireburn i særudstillingen Stop slaveri! der vises I 2017, og Ehlers' skulptur af Queen Mary siddende på en trone kommer med al sandsynlighed til at pryde pladsen foran Vestindisk Pakhus i København.

\section{PLANTAGEEJERNES SKURK ELLER ARBEJDERNES HELT: DAVID HAMILTON JACKSON}

David Hamilton Jackson er en af det tidlige 20. århundredes caribiske helte. Som borgerrettigheds- og arbejderrettighedsforkæmper var han frontfigur i en bevægelse, der krævede sociale, økonomiske og politiske reformer i det danske styre af kolonien, der på det tidspunkt var i åbenlys tilbagegang. Slaveriet blev afskaffet i 1848 og Fireburn i 1878 havde ført til små forbedringer for de frie afrikansk-caribiske arbejdere, men sukkerindustrien var i kraftigt nedgang og Danmark, moderlandet, havde ikke noget incitament til at investere i øerne. Afrikansk-caribiere blev betalt meget lave lønninger, havde få rettigheder og stort set ingen indflydelse. Desuden var samfundshierarkiet fra før slaveriets afskaffelse stadig stort set intakt: Problemerne i kolonien var både politiske, økonomiske, sociale og racistiske (Hall, 1992).

Jackson rejste til Danmark I 1915 og tiltrak sig en del opmærksomhed gennem taler og møder særligt blandt danske socialdemokrater, som han håbede at opnå støtte fra. Jackson vendte dog tilbage til øerne uden mere substantielle løfter om forandringer. Men det lykkedes ham at få afskaffet forhåndscensuren, og den nyligt tilkæmpede trykkefrihed gjorde det muligt for ham at etablere den første frie avis i Dansk Vestindien, The Herald. Han organiserede også den første fagforening i Dansk Vestindien, som gennem generalstrejker opnåede højere lønninger og bedre arbejdsforhold (Hoxcer Jensen, 1981). På Jomfruøerne betragtes Jackson i dag som folkets helt, en principfast og modig mand. I førsteudgaven af The Herald, fremgår 
det af et brev til redaktøren at:

Mange datoer i historien markerer, hvad vi kalder "slaveriets ophævelse" i et eller andet land. Slaverne i Dansk Vestindien blev frigjorte på én given dato, slaverne i de britiske kolonier på en anden og så videre. Men denne dag markerer en anden slags "ophævelse" for befolkningen på St. Croix. I dag, for første gang i denne øs historie, bliver en avis udgivet "for den sag, der mangler bistand". En avis ejet af folket, redigeret og udgivet af folket, for folket (Leader, 1915)

På den sidste side i samme avis, udråber Jackson 1. november som Liberty Day: Denne dag skal gå over i historien som Liberty Day. Andre lande har en arbejdernes kampdag, en uafhængighedsdag, en flagets dag, på hvilke disse lande markerer begyndelsen på en ny epoke i deres historie. Vi vil, at vort folk for evigt holder denne dag, den første november, i hævd som deres nationaldag Jackson, 1915).

Hvor Buddhoe og Fireburn-dronningerne kan forekomme flygtige i kildematerialet, eftersom de kun optræder i enkelte retsprotokoller og fængselsjournaler, har Jackson efterladt sig en rig arv af skrevne kilder. ${ }^{5}$ Disse bærer vidne om en intellektuel og visionær personlighed, som viede sit liv til at reformere og forbedre arbejderklassens forhold i Dansk Vestindien. Jackson blev "arbejdernes helt" og "plantageejernes skurk". Han blev muligvis taget vel imod under sit besøg I Danmark, men hans opførsel var en torn i øjet på koloniadministrationen i Dansk Vestindien. Holger Petersen, som var talsperson for Det Konservative Folkeparti i 1916, argumenterede for at Jackson var optændt af racistisk had mod danskerne:

Det er det rene Racehad, han prædiker, og han kræver, at al Jord skal tilhøre Negrene, og de Hvide skal forjages fra Øen. [...] Med velberaad Hu og aabenlyst prækes Racehad, og der er skabt et Modsætningsforhold, en Mistillid og et Had, som aldrig før har eksisteret paa vore Øer (Lehman, 1916).

På Jomfruøerne fejres 1 . november - det vil sige dagen for den første udgave af The Herald - stadig som en årlig offentlig fridag. Dagen har heddet Liberty Day, Bull and Bread Day (en festdag med kød og brød) - og på det seneste David Hamilton Jackson Day. Et boligkvarter i Christiansted, St. Croix er blevet opkaldt efter ham, og man har opsat en bronzebuste af ham i Frederiksted. Prototypen af denne buste er en af de 3 skulpturer, som man skænkede til Danmark i 2016. Den vil blive udstillet på Arbejdermuseet ved siden af førsteudgaven af The Herald, Jacksons brev 
til kongen og andet arkivmateriale, der har at gøre med arbejderorganisering på St. Croix i årene op til 1917.

\section{HOLD INTERESSEN I LIVE}

Buddhoe, Fireburn-dronningerne og Jackson blev aldrig betragtet som danske, selvom de alle boede i en dansk koloni og var underlagt danske koloniallove. De blev tværtimod betragtet som afrikansk-caribiere, som aktivt gjorde modstand mod det danske styre. I 1916 skrev forfatteren og meningsdanneren Emma Gad om de afrikansk-caribiske indbyggere, at de måtte betragtes som:

saa dybt forskellige fra os i Race og Farve, i Sprog og Tankesæt, at man har haft svært ved at indordne dem under Begrebet Landsmandinder. Ikke saa underligt, for de sorte Beboere af disse Øer er jo ikke vore Landsmænd, men et tilklistret unaturligt Anhang til os (Lehman, 1916).

De afrikansk-caribiske helte og de fortællinger der knytter sig til dem introducerer "andre" stemmer, som tillader et glimt af det koloniserede flertals tilværelse. De fremstiller ikke afrikansk-caribiere som simple ofre eller som "unaturligt Anhang" som er "tilklistret os", men som mennesker med handlekraft og en stærk vilje til at gøre noget ved de uretfærdigheder, det danske kolonisystem udsatte dem for. Fortællinger om kamp og engagement er ofte overbevisende og gør historiefaget nutidigt og relevant.

Det forhold, at fortællingerne om Buddhoe, Fireburn-dronningerne og Jackson er blevet fortalt på meget forskellige måder af henholdsvis kolonimagten og de koloniserede, maner til eftertænksomhed og diskussion. Modsætningerne mellem de to positioner viser, at historie er et dynamisk studie, der kan forstås på mere end en måde. I en dansk kontekst tvinger det os til at gentænke, hvem "vi” er villige til at acceptere som danske helte. Til spørgsmålet om, hvorvidt den tidligere kolonimagt kan acceptere helte, som ikke er hvide, men som nedstammer fra mennesker, der blev gjort til slaver af danskere, og som gjorde modstand mod det danske styre, er svaret: Ja, afgjort. Hvis den moderne danske indstilling vitterlig er, at slaveriet var en uhyrlighed, og at von Scholten er en helt, fordi han afskaffede slaveriet, så skal de afrikansk-caribiere, der bekæmpede undertrykkerne, både før og efter slaveriets afslutning, også anerkendes og indtage deres retmæssige plads som helte i den dan- 
HALBERG \& COLEY

ske historieskrivning.

\section{LITTERATUR}

Andersen, Astrid Nonbo (2013): We have reconquered the islands: Figurations in Public Memories of Slavery and Colonialism in Denmark 1948-2012. International Journal of Politics, Culture and Society, 26.

Bastian, Jeannette Allis (2003): Owning Memory: How a Caribbean Community Lost its Archives and Found its History. Libraries Unlimited.

Bjerregaard, Jørgen O. (1991): Fra slavesang til Soca: Historien om og musikken fra de tidligere Dansk-Vestindiske Øer. Dansk Vestindisk Selskab.

Bjørn, Anders (2016): Rejs et monument, der kan minde os om vores 333 år som kolonimagt. Politiken, 5/10, 2016.

Christianshavns Straffeanstalt, Protokol over kvindefanger m.fl. (1854-1925), 1882-1887. Rigsarkivet.

Damkjær, Nicklas Weis \& Scherfig, Albert (2016): Kvinderne i Danmarks største arbejderopstand. Friktion, nr. 10, årg. 3.

David, C.N. (1848): Vestindien. Fodrelandet, August, 1848.

Halberg, Rikke Lie \& Coley, Bertha Rex (2016): Dansk Vestindien - fra dansk koloni til amerikansk territorium. Frydenlund.

Halberg, Rikke Lie (2016a): Dansk Vestindien på Museum: Brud og kontinuitet i udstillingspraksis 1888-2013. Masterafhandling, Lunds universitet.

Halberg, Rikke Lie (2016b): Fireburn Queens. Historiskan, 1/2016.

Halberg, Rikke Lie \& Christensen, Jens (2017): Punkt på tidslinjen 1917: Da Danmark solgte Dansk Vestindien. Alinea.

Hall, N.A.T (1992): Slave Society in the Danish West Indies. Ed. B.W. Higman, The University of the West Indies Press.

Hill, R. (1983): Clear de Road. A Virgin Islands History Text Book. U.S. Virgin Islands Dept. of Conservation and Cultural Affairs, Bureau of Libraries, Museums, and Archaeological Services.

Hoxcer Jensen, Peter Hoxcer (1998): From Serfdom to Fireburn and Strike. A History of Black Labour in the Danish West Indies 1848-1916. Antilles Press.

Hoxcer Jensen, Peter Hoxcer (1981): Den dansk vestindiske arbejderbevægelse og strejken i 1916. Meddelelser og forskning i Arbejderbevoegelsens Historie, nr. 16. 
Illustreret Tidende (1878). Årgang 20, nr. 997, nr. 03/11, 1878.

Jackson, D.H. (1915): Liberty Day. The Herald, November, 1915.

Jensen, Nicklas Thode (2006): For slavernes sundhed. Københavns Universitet.

Knox, John P.A. (1852): Historical Account of St Thomas, W. I. Charles Scribner.

Leader, R.H. Amphlett (1915): To the Editor of 'The Herald'. The Herald, November, 1915.

Lehmann, Johannes, ed. (1916): For eller Imod, Udtalelser med henblik paa det eventuelle salg af de danske vestindiske øer. Lehmann \& Stage.

Marsh, Clifton E. (1981): A Socio-Historical Analysis of the Labor Revolt of 1878 in the Danish West Indies. Phylon, vol. 42, 4th Quarter.

Oliver, M. Cynthia (2009): Queen of the Virgins: Pageantry and Black Womanhood in the Caribbean. University Press of Mississippi.

Olvig, Karen Fog (1985): Hvad skal vi med dansk kolonihistorie? Fortid og Nutid, nr. 32.

Rothstein, Klaus (2015): Et monument for de slavegjorte. Weekendavisen, 4/9, 2015.

Rostgaard, Marianne \& Schou, Lotte (2010): Kulturmøder i dansk kolonihistorie. Gyldendal.

Sebroe, Louise (2010): Mellem afrikaner og kreol: etnisk identitet og social navigation i Dansk Vestindien 1730- 1770. Lunds universitet.

Simonsen, Gunvor (2007): Slave Stories: Gender, Representation and the Court in the Danish West Indies, 1780s - 1820s. The European University Institute.

Sørensen, Niels Arne (2010): Erindringsteder. Noter - Historieloererforeningen for Gymnasiet og HF, nr. 185.

Willocks, Harold W.L. (1995): The Umbilical Cord - The History of the United States Virgin Islands from Pre-Columbian Era to the Present. Harold W. L. Willocks.

NOTER

1 F.eks. Olvig (1985), Hall (1992), Thode Jensen (2006), Simonsen (2007), Sebroe (2010).

2 Rostgaard \& Schou (2010), Halberg \& Coley (2016), Halberg \& Christensen (2017)

3 F.eks. Arbejdermuseet, Det Kongelige Bibliotek, Holbæk Museum, Statens Museum for Kunst.

4 Avisen Fodrelandet udkom mellem 1843-1882.

5 The Herald er for nyligt blevet digitaliseret og tilgængeliggjort af Statsbiblioteket. Rigsarkivet har digitaliseret alt kildemateriale med relation til Dansk Vestindien, herunder Jacksons korrespondance. 
